\title{
Analysis of Online Business Management During Covid-19 Pandemic
}

\author{
Sri Umi Mintari ${ }^{1 *}$, Sri Handayani ${ }^{2}$, Dian Rachmawati ${ }^{3}$, Ahmad Munjin Nasih ${ }^{4}$, \\ Halimah Binti Mohd Yusof ${ }^{5}$
}

1,2,3,4 Universitas Negeri Malang, Malang, Indonesia

${ }^{5}$ Universitas Teknologi Malaysia, Johor Bahru, Malaysia

*Corresponding author. Email: sri.handayani.fe@um.ac.id

\begin{abstract}
Online business is currently booming and growing rapidly. The Covid-19 pandemic has forced all sectors to impose social restrictions. It also certainly has an impact on businesses. Businesses made offline must simultaneously turn strategies into online businesses. Therefore, the proficiency of female businesspeople should be able to take advantage of the opportunities that exist in society. The purpose of this research is to: 1) know the business condition of Online Business in female business people and 2) know online business management in the covid-19 pandemic? The method used in this study is the qualitative method through interview instruments. The results showed that of the 5 respondents interviewed the current condition of covid-1 the business can still run but must adjust to the current pandemic situation and conditions by diversifying products according to market demand to provide health-focused goods to prevent the Covid-19 virus. While the management of online business that is done can be seen from the aspect of human resources is already well owned because the average educated S1, financial aspect has not done separation of personal financial management and still has not routinely recorded financial statements, the production aspect is still only doing production without using advanced tools but the packaging is already premium class, and the promotional aspect utilizes social media to boost purchases.
\end{abstract}

Keywords: Online business, Female entrepreneurs, Covid 19 pandemic.

\section{INTRODUCTION}

During the Covid-19 pandemic ability to manage the business effectively became very important. Especially in online businesses run by female businesspeople. The role of women today is increasing in economic activity. In 2013, a survey by the National Association of Women Business Owner showed that since 2013 business ownership by women has increased from $81 \%$ of female entrepreneurs feeling optimistic about their current business performance [1]. This phenomenon is due to the rapid growth of the digital age so there is a stronger motivation for women to break down male domination in the industry and open opportunities for women to have the opportunity to open their businesses. Many women's success stories manage a business with the sovereignty it has. The creativity and innovation of women entrepreneurs can be a success of the business of female businesspeople to become independent.
Different types of businesses are also in demand by female entrepreneurs. Includes online business.

The role of women in online businesses needs to be analysed even more. Online Business consists of 2 words namely Business and Online. If viewed the definition of Business is a business or activity carried out by the group or individuals to profit by producing products and services to meet the needs of its consumers. While the word Online according to dictionaries and experts is an activity connected through a computer network that can be accessed through other computer networks. Basically, online business is also commonly called BO. In its implementation now online business in Indonesia is increasingly showing significant development. Online business, not only monopolized by shopping for goods, but also services such as banking that introduce e-banking techniques, electronic money for transactions currently or online business for the purchase of an item is experiencing a 
considerable development. Starting from sites that sell mobile phones, guitars, boutiques, bookstores, food, even to electronic devices are starting to be worshipped by online business services.

Female businesspeople in Tulungagung Regency are also experiencing the rapid development of technology. This can be seen from women's understanding that smartphone technology can be used as a means to earn income. The businesswoman is also involved in the electronic marketplace through Facebook, Instagram or WhatsApp. Based on this, the purpose of the research in this case is to: 1) know the business condition of Online Business in female business people and 2) know online business management in the covid-19 pandemic?

\section{METHOD}

The design of this study uses a descriptive qualitative research design. This research will describe the financial literacy of millennial women in managing online businesses in Tulungagung Regency. The phenomenon is based on the financial literacy of millennial women in managing online businesses in Tulungagung Regency. The selection of the design of this study is based on a phenomenon that occurs is a new subject and excavated from the direct speech of the research subjects. The object of the research in this study is also primary data which is the perception of the research subjects related to the problem of the study language. So, the data that is expected to be collected is verbal data that provides a clear picture related to the problem of research.

The subjects of this study were millennials 17 years to 35 years old. Which is where the subject is the woman who owns the online business. So, this will show the financial literacy of millennial women in managing online business in Tulungagung Regency accurately and precisely.

The research instrument of this research uses three research instruments, namely observation sheets conducted both before and after, questionnaires and indepth interviews to obtain accurate and stable information.

Data collection is done by observation. This activity was conducted to obtain data on the financial literacy of millennial women in managing online businesses in the integrated Tulungagung Regency. Observations were made before to find out how the financial literacy of millennial women in managing online businesses in Tulungagung Regency. In-depth interviews were conducted to get clear data on the financial literacy of millennial women in managing online businesses in Tulungagung Regency. Data Analysis conducted namely (1) Data reduction, this activity is carried out to sort the data obtained from observations and interviews.
Data that does not match the study is released from an existing data set. Furthermore, the appropriate data will be used further activities, (2) Mature data, is data that has been sorted and has been classified according to the needs of research data. This data shows the adequacy of the requested data so that it can be withdrawn an initial collection as a finding, (3) From the results of the data will be made a data finding and a temporary conclusion related to the data yang has been found in the field, (4) If indeed the collected data has not met the sufficient data analysis then it will be added with additional data to provide the information needed in the research. (5) From the preliminary conclusions and data collected will be triangulated to check the validity of the findings and the validity of the data related to the findings. So that an absolute and final conclusion can be drawn.

\section{RESULTS AND DISCUSSION}

Based on the results of the research conducted obtained the following data:

\subsection{Description of Overview}

Tulungagung regency located in the southern region of East Java Province is astronomically located at $111^{\circ} 43^{\prime}-112^{\circ} 07^{\prime}$ east longitude and $7^{\circ} 51^{\prime}-8^{\circ} 18^{\prime}$ south latitude and borders Kediri Regency to the north, Blitar Regency to the east, Indian Ocean to the south and Trenggalek Regency to the west. Tulungagung regency has an area of $1,055.7 \mathrm{~km}^{2}$ consisting of land, mountainous areas and coastal areas. This condition makes Tulungagung Regency has a variety of potential resources such as food crops, plantations, and fisheries. Tulungagung regency is administratively divided into 19 sub-districts, 271 villages/ villages, with the largest number of villages in Gondang sub-district as many as 20 villages and the smallest number of villages in Tanggunggunung sub-district as many as 7 villages. Tulungagung regency is divided into three plateaus namely high, medium and low. The lowlands cover all villages /villages except some Pagerwojo sub-districts (4 villages) and some Sendang sub-districts (4 villages). The plain covers part of Pagerwojo Sub-District (6 villages) and part sendang sub-district (5 villages). The highlands include part of Pagerwojo Sub-District (1 village) and part sendang sub-district (2 villages). From this area has quite a potential population. As seen in the chart below.

Table 1. Population indicator of Tulungagung regency

\begin{tabular}{|l|r|r|r|}
\hline \multicolumn{1}{|c|}{ Indicators } & $\mathbf{2 0 1 7}$ & $\mathbf{2 0 1 8}$ & $\mathbf{2 0 1 9}$ \\
\hline Total Population (000 Java) & 1.031 & 1.035 & 1,039 \\
\hline Increase Population (\%) & 0.46 & 0.44 & 0.36 \\
\hline Density (person $/ \mathrm{km}^{2}$ ) & 976 & 981 & 984 \\
\hline Sex ratio & 95 & 95 & 95 \\
\hline Number of household (000) & 291 & 292 & 299 \\
\hline $\begin{array}{l}\text { Average population per } \\
\text { household }\end{array}$ & 4 & 4 & 3 \\
\hline
\end{tabular}

Source: Tulungagung District Statistics (2019/2020) 


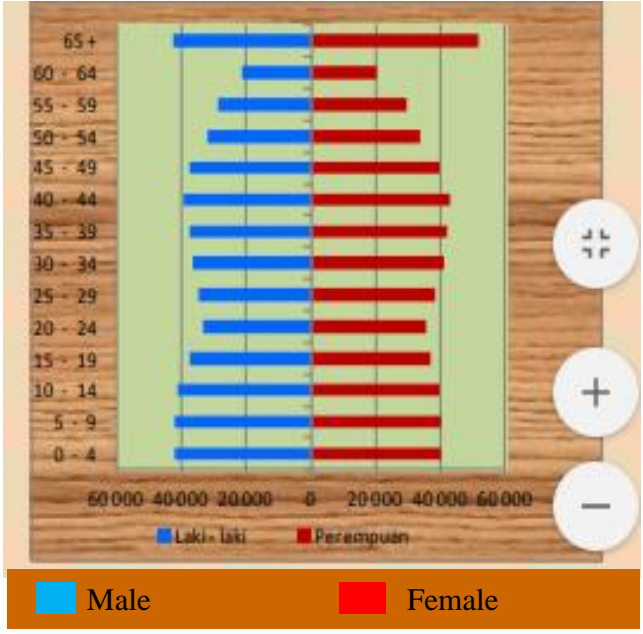

Figure 1. Pyramid of Tulungagung people Source: Tulungagung District Statistics (2019/2020)

From the table 1 and figure 1 above it can be seen that a significant increase in the population coupled with the spread based on gender between men and women is more female for the age of $30-39$ years. This can affect working conditions. In more detail can be seen in figure 2 below about The Percentage of Workers by Main Employment Status in Tulungagung Regency 2019.

Based on figure 2 below it is known that entrepreneurship takes a share of $19.62 \%$ of the overall work. If viewed from the data then actually entrepreneurs simply take a strategies role in the economy in Tulungagung Regency. If viewed the type of business field can be seen in table 2 below.

Table 3. Respondents who have the highest turnover

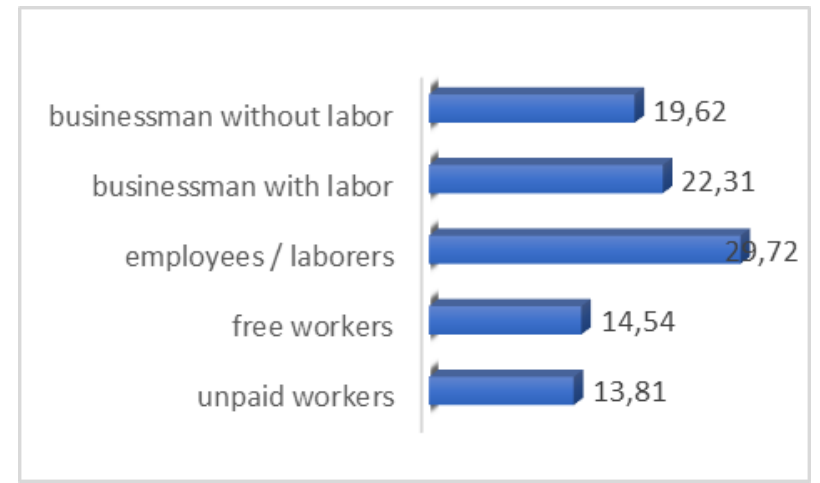

Figure 2. Percentage of Workers by Primary

Employment Status in Tulungagung Regency 2019

Source: Tulungagung District Statistics (2019/2020)

Based on table 2 below that the field of business that is much in demand is jasa business. This is certainly very impactful for Online businesspeople.

Table 2. Residents working by business type

\begin{tabular}{|l|c|c|c|}
\hline \multicolumn{1}{|c|}{ Business Field } & $\mathbf{2 0 1 7}$ & $\mathbf{2 0 1 8}$ & $\mathbf{2 0 1 9}$ \\
\hline Agriculture & 33.92 & 36.82 & 32.38 \\
\hline Manufacture & 26.79 & 25.96 & 28.56 \\
\hline Service & 39.29 & 38.23 & 39.07 \\
\hline
\end{tabular}

Source: Tulungagung District Statistics (2019/2020)

\subsubsection{Respondent Information}

Respondents taken in the This study are 5 respondents who are female entrepreneurs in the millennial era. Here's an overview of respondents on table 3 below.

\begin{tabular}{|l|c|c|c|c|c|}
\hline \multicolumn{1}{|c|}{ Indicator } & $\mathbf{A}$ & $\mathbf{B}$ & $\mathbf{C}$ & $\mathbf{D}$ & $\mathbf{E}$ \\
\hline \multicolumn{1}{|c|}{ Age (Year) } & $\mathbf{2 9}$ & $\mathbf{3 4}$ & $\mathbf{3 2}$ & $\mathbf{3 7}$ & $\mathbf{3 2}$ \\
\hline Type of business & $\begin{array}{c}\text { Peanut sauce/ } \\
\text { Chili }\end{array}$ & $\begin{array}{c}\text { Al-Qur'an } \\
\text { electronic }\end{array}$ & Clothing & $\begin{array}{c}\text { Catering, Rice and } \\
\text { snack box) }\end{array}$ & Cosmetics \\
\hline Period of time & 5 years & 1 years & 5 years & 9 years & 3 years \\
\hline Omzet (month) & 2.500 .000 & 1.750 .000 & 1.800 .000 & 3.250 .000 & 1.450 .000 \\
\hline Ownership type & $\begin{array}{c}\text { Individual } \\
\text { company }\end{array}$ & $\begin{array}{c}\text { Individual } \\
\text { company }\end{array}$ & $\begin{array}{c}\text { Individual } \\
\text { company }\end{array}$ & $\begin{array}{c}\text { Individual } \\
\text { company }\end{array}$ & $\begin{array}{c}\text { Individual } \\
\text { company }\end{array}$ \\
\hline
\end{tabular}

Based on Table 3 above of the 5 respondents who have the highest turnover is catering business and when viewed from the age of the respondent is in the range of 29 - 37 years according to the characteristics of millennial age. In the table it can also be known that the business owned is a type of individual business that is managed independently. Various types of businesses that have food businesses and other businesses.

\subsubsection{Online Business Conditions}

Based on the results of interviews conducted online business conditions from 5 different respondents. This is because in the time of covid pandemic the type of goods needed by the community more leads to the fulfilment of basic needs and health goods. This represents a decline in purchasing power in the electronics, cosmetics and apparel businesses. Therefore, female businesspeople immediately make adjustment changes to existing conditions.

So that the variant of goods sold also adjusts the demand. These changes/innovations are:

1) Food and catering businesses add product variants by producing foods that to improve the immune system such as traditional herbal drinks (herbal medicine) and other healthy food snacks.

2) Clothing business sells clothes for home use 
and masks according to medical standards

3) Cosmetics businesses sell Face Shield and hand sanitizers that are increasingly in demand

\subsubsection{Online Business Management}

From research data it can be seen that the management of online business that has been run is proven quite well in terms of human resources aspect, financial aspect, production aspect and promotion aspect.

\subsection{Discussion}

\subsubsection{Online Business conditions in female businesspeople}

Based on the results of online business research conducted by business women ranging in age from 29 37 years in Tulungagung district namely food business (Peanut Chili Sauce and Catering Business), Non-food (Al-Qur'an electronics, Clothing, and Cosmetics). From this if viewed from the type of services and industry individuals. The business conditions experienced by female businesspeople are adapted to the current situation of covid pandemic. With the pandemic, entrepreneurs have to adjust the production factor. The production factors available in the economy are distinguished in 4 types namely natural resources, labour, capital and expertise [2]. There is a special skill of making one's initial capital in opening a business by considering the opportunities that exist around it and taking risks that could happen.

\subsubsection{Online Business Management during covid-19 pandemic}

In doing business management online is done looking at from the aspect of human resources already well owned because the average high school educated, bachelor degree and master degree. This means that the academic ability of female businesspeople is good. To manage a business requires good personal skills one of which is seen from the level of education.

As for the financial aspect has not done separation of personal financial management and still has not routinely recorded financial statements. From this it shows that from the financial aspect still has low literacy. Some studies have shown that low financial literacy is a result of a lack of financial knowledge [3] A person whose financial literacy rate is low usually correlates with low income, low education, and low wealth [4]. Therefore, increased financial knowledge for households is necessary in order for them to participate sustainably in the money market [5].

Financial literacy is also related to behaviour [6]. A person's financial behaviour can be measured by their behaviour in managing basic finances, for example in by the public due to covid-19 pandemic.

terms of saving, consumption, even investment. A person's financial behaviour can also be demonstrated by a person's participation in buying financial products, such as buying stocks, bonds, gold, foreign exchange, term deposits. Someone participating in the stock market tended to have a high level of financial literacy [4].

Financial attitudes are measured by a person's attitude to money and financial responsibility. Respondents' attitudes to risk correlated with shareholding. Those who do not want to take risks are less likely to participate in the stock market. Therefore, financial attitude is one of the measures to measure the level of financial literacy of a person [8]. Financial attitudes correlate with the level of financial problems [9].

For production aspect still do production in a simple way without using advanced tools but packaging is already premium class. Production activities are activities that convert inputs into an output to increase benefits by changing shape, moving places and storing [10]. This is in line with that done by business women in Tulungagung Regency by converting natural ingredients into food that can be used to earn income.

The promotional aspect utilizes social media to boost purchases. This is classified as online marketing by businesspeople. Online marketing is defined as an effort to market products and services and build relationships with customers through internet media [11]. The results are also in line with the results of a previous relevant study with entitled "Economic Literacy and Digital Literacy: Case Study on Phinisi Boat Craftsmen in Bontobahari District bulukamba regency" which states that Economic literacy and digital literacy have a connection in improving the economy among phinisi boat craftsmen [12]. Advances in technology, computers, and telecommunications support the development of internet technology. With the internet the craftsmen no longer have difficulty in obtaining any information, to support their business activities.

\section{CONCLUSION}

The results showed that of the 5 respondents interviewed the current condition of covid-1 the business can still run but must adjust to the current pandemic situation and conditions by diversifying products according to market demand to provide healthfocused goods to prevent the Covid-19 virus. While the management of online business that is done can be seen from the aspect of human resources is already well 
owned because the average educated S1, financial aspect has not done separation of personal financial management and still has not routinely recorded financial statements, the production aspect is still doing production in a simple way without using advanced tools but packaging is already premium class, and the promotional aspect utilizes social media to boost purchases.

\section{AUTHORS' CONTRIBUTIONS}

The first author as the person in charge and determinant of the research topic and provides the basic concept of research development. the second author compiles article 1, literature review and research methods, the third author is the compiler of article 2 and data processor. the fourth author is the evaluator and reviewer of articles 1 and 2 . and the fifth writer is the mentor and reviewer of the articles to be submitted in journals or proceedings

\section{ACKNOWLEDGMENTS}

We would like to express our gratitude to research and community service institutions (LP2M) of Malang State University which has facilitated and provided funding for this research. the informants and field workers who assisted us in completing this research and article.

\section{REFERENCES}

[1] Helmiatin. "Womanpreneur di Indonesia, kewirausahaan dalam multiperspektif'. Universitas Terbuka Repository.

[2] Y. E. A. Seputra, J. Sutrisno, Pengantar ekonomi mikro. Ekuilibria. Yogyakarta. 2016

[3] H. Chen and R. P. Volpe. "An analysis of personal financial literacy among college students."
Financial Services Review, 7(2), pp 107-128. 1998 doi: 10.1016/S1057-0810(99)80006-7.

[4] A. Lusardi and O. S. Mitchell. "The economic importance of financial literacy: theory and evidence". 52(1). pp1-40. 2014 doi: http://dx.doi.org/10.1257/jel.52.1.1.

[5] R. Ramakrishnan. "Financial literacy-the demand side of financial inclusion." SSRN Electronic Journal. 2011. doi: https://doi.org/10.2139/ssrn.1958417.

[6] A. Firli. "Factors that influence financial literacy: a conceptual framework," pp. 1-7. 2017. doi: 10.1088/1742-6596/755/1/011001.

[7] A. Lusardi and O. S. Mitchell. "The economic importance of financial literacy: theory and evidence". 52(1). pp1-40. 2014 doi: http://dx.doi.org/10.1257/jel.52.1.1.

[8] C. Hayhoe, L. Leach, \& P. Turner. "Discriminating the number of credit cards held by college students using credit and money attitudes." Journal of Economic Psychology, 20(2), 643-656. 1999.

[9] 2016. Herdjiono \& Damanik. "Pengaruh financial attitude, financial knowledge, parental income terhadap financial management behavior", Universitas Musamus. [online] available https://ejournal.unair.ac.id

[10] Suhardi. "Pengantar ekonomi mikro". Yogyakarta: Gava Media. 2016

[11] P. Kotler, \& K.L.Keller. "Marketing management, 13th edition.” New Jersey: Pearson Prentice Hall. 2009.

[12] 2019. A.P. Jafar. "Literasi ekonomi dan literasi digital (studi kasus pada pengrajin perahu phinisi di Kec. Bontobahari Kab. Bulukumba)”. [Online] available http://eprints.unm.ac.id/13706/ 